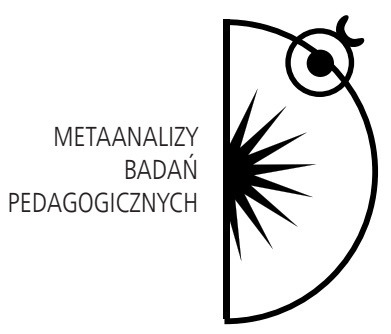

Violetta Kopińska

\title{
Rekonstrukcja kultury prawnej szkoły na podstawie (zmian) przepisów prawnych w zakresie nadzoru pedagogicznego
}

DOI: http://dx.doi.org/10.12775/PBE.2013.019

\section{Wprowadzenie}

Wśród czynników rozwojowych szkoły wymienia się m.in. politykę oświatową państwa (w tym jakość prawa oświatowego) oraz sprawność organizacyjną i kierowniczą w szkole (Olejniczak, Pielachowski, 2004, s. 161). Oba te czynniki łączy pojęcie nadzoru pedagogicznego. $Z$ jednej strony jest on formą zarządzania szkołą, z drugiej - „narzędziem” polityki oświatowej państwa. Jednak jak piszą Olejniczak i Pielachowski, sprawna organizacja i kierownictwo niewiele pomogą, jeżeli „polityka oświatowa, w tym system prawa oświatowego będą nieklarowne, chaotyczne [...]" (Olejniczak, Pielachowski, 2004, s. 161). W Polsce od 1989 r. następowały zmiany w zakresie zarządzania oświatą. Postulowano decentralizację, autonomię i samorządność szkół. Czy to się udało? Po przeszło 20 latach wielu uważa, że ogromna część tych zmian miała charakter pozorny (Śliwerski, 2013, s. 110), współczesny system oświatowy jest hiperadministracyjny, a „Ekonomizacja, biurokratyzacja, ideologizacja i masowa kultura zniekształcają [go - przyp. V. K.] [...] ograniczając i tak labilną wolność pedagogiczną różnych organów szkolnych" (Śliwerski, 2013, s. 105). Obecne zarządzanie oświatą jest nacechowane hierarchicznością i nie sposób 
nie zauważyć, że dominująca rola przypada szczeblowi centralnemu, odpowiedzialnemu również za kreowanie prawa w dziedzinie oświaty (w tym także tego, które dotyczy samego nadzoru pedagogicznego). Ma to istotne znaczenie dla kultury organizacyjnej szkoły, która zależy również od czynników zewnętrznych (Pająk, 1996, s. 30-32), i - zdaniem Szempruch - może przejawiać się również w płaszczyźnie funkcjonowania ludzi w systemie oświatowym oraz organizacji nadzoru pedagogicznego (Szempruch, 2001). Kultura ta natomiast wywiera wpływ na powodzenie szkoły i jej efektywność (Karcz, 2010, s. 211). Kształt prawa zatem, jego zmiany, a także powody tych zmian mają istotne znaczenie dla funkcjonowania szkoły w społeczeństwie, a w zakresie kultury organizacyjnej szkoły niebagatelną rolę odgrywają regulacje związane z nadzorem pedagogicznym.

Pojęciem, które wydaje się spinać interesujące mnie tu zagadnienia, jest pojęcie kultury prawnej szkoły. W niniejszym artykule spróbuję dokonać jej rekonstrukcji na podstawie regulacji prawnych związanych z nadzorem pedagogicznym.

Zanim jednak zdefiniuję kulturę prawną szkoły, rozpocznę od kilku uwag ogólnych, które będą stanowić bazę dla moich dalszych rozważań.

Po pierwsze - w podejściu do prawa przyjmuje perspektywę kulturalistyczną. Zgodnie z nią ,prawo jest specyficznym językiem danej kultury i [...] odzwierciedla sposoby organizacji charakterystyczne dla rozmaitych grup ludzkich" (Dupret, 2010, s. 15). Nie oznacza to jednak tylko biernego odzwierciedlenia. Jak pisze Geertz ,prawo nie jest jedynie dodatkiem do moralnie (lub niemoralnie) ukształtowanego już społeczeństwa, lecz jest aktywną jego częścią, włącza się w nurt innych zjawisk kulturowych [...]" (Geertz, 2005, s. 214).

Po drugie, pojęcie kultury prawnej może być definiowane w trzech zasadniczych aspektach: poznawczym, emocjonalnym i behawioralnym (Szubert, 1983, s. 575-576). Aspekt poznawczy oznacza utożsamianie kultury z wiedzą prawniczą i jej rozpowszechnieniem w szerszych kręgach społeczeństwa. Aspekt emocjonalny z kolei, to ukształtowane przekonania, postawy, wartości i oparte na nich oceny prawa. Trzeci aspekt - behawioralny - ujmuje kulturę prawną jako całość kultury zachowania się odpowiadającą prawu pozytywnemu (albo określone jej przejawy, w szczególności działania realizujące wzory symboliczne zawarte w prawie) (Szubert, 1983, s. 575-576). Zgodnie z koncepcją Szuberta nie traktuję wyżej wskazanych ujęć kultury prawnej jako alternatywnych. Jednocześnie uważam za istotne wyróżnienie w ramach kultury prawnej: kultury tworzenia stosowania oraz kultury przestrzegania prawa (Szu- 
bert, 1983, s. 577). Te przenikające się i warunkujące wzajemnie zakresy są szczególnie przydatne dla celów analitycznych.

Na tym tle kultura prawna szkoły jest przeze mnie rozumiana jako:

a) przekonania, postawy wobec prawa związanego $\mathrm{z}$ funkcjonowaniem szkoły i podstawowych podmiotów edukacyjnych, oparte na nich oceny prawa;

b) przejawy zachowania podmiotów edukacyjnych oraz organów szkoły oparte zarówno na regulacjach prawnych, jak i wynikające z postaw wobec prawa;

c) regulacje prawne, dotyczące funkcjonowania szkoły i podmiotów edukacyjnych, które:

- są wyrazem zarówno określonych przekonań i stosunku wobec prawa w ogóle, jak i stosunku do szkoły oraz interpretacji jej roli w społeczeństwie i w edukacji (dotyczy to także poszczególnych procesów, mechanizmów, procedur lub działań, które mają miejsce w szkole),

- są wyrazem znaczenia, jakie w danym społeczeństwie przypisuje się mechanizmom prawnym jako regulatorom funkcjonowania szkoły zarówno w wymiarze organizacyjnym, jak i instytucjonalnym,

- wpływają na zakres emocjonalny i behawioralny kultury prawnej szkoły (punkt a i b).

\section{Uwagi metodologiczne}

Niniejszy artykuł stanowi fragment szerszej analizy związanej z podejmowaną tu tematyką kultury prawnej szkoły. W tym jednak miejscu skupiam się jedynie na jednym komponencie kultury prawnej szkoły - regulacjach prawnych, które traktuję jako tekst kultury. Jako przykład wybrałam przepisy prawne związane $\mathrm{z}$ nadzorem pedagogicznym. Problem badawczy, postawiony w ramach tego opracowania brzmi: „Jakie cechy kultury prawnej szkoły wynikają z regulacji prawnych związanych z nadzorem pedagogicznym?". Należy przy tym podkreślić, iż zdaję sobie sprawę z ograniczeń w tym zakresie. Uzyskane wyniki nie muszą bowiem w rezultacie wpisywać się w „kanon cech” dystynktywnych dla kultury prawnej szkoły, a dokładnie tego jej komponentu, który wiąże się z szerszym zakresem regulacji dotyczących funkcjonowania szkoły oraz jej podmiotów edukacyjnych. Niemniej jednak wybór tematyki został podyktowany rangą przypisywaną nadzorowi pedagogicznemu w ramach praktyki edukacyjnej szkoły. 
Odwołując się do symptomów dysfunkcjonalności kultury prawa ${ }^{1}$ wyróżnionych przez Kojdera (1995, s. 255) - jako kategorie analizy wyselekcjonowałam:

- stabilność regulacji prawnych w tym zakresie,

- spójność regulacji prawnych rozumianą jako brak wewnętrznych sprzeczności wynikających z wykładni prawnej i/lub brak sprzeczności między artykułowanymi celami nadzoru pedagogicznego a wykładnią szczegółowych regulacji prawnych,

- stopień nasycenia tej dziedziny regulacjami i przepisami prawnymi w odniesieniu do poprzednio obowiązujących regulacji prawnych (liczba aktów prawnych, stopień proceduralizacji w tej dziedzinie, obszary regulacji prawnych).

\section{Stabilność regulacji prawnych w zakresie nadzoru pedagogicznego}

Stabilność aktów prawnych jest jednym z tych czynników, który zwiększa poczucie bezpieczeństwa prawnego i wzmacnia autorytet prawa (Kojder, 1995, s. 255). Istnieją także inne korzyści wynikające $\mathrm{z}$ tego, że prawo jest w miarę stałe. Oceny takiego prawa mogą wynikać z jego rzeczywistego kształtu, a nie $\mathrm{z}$ wyobrażenia na jego temat, co stwarza $\mathrm{z}$ kolei większą szansę na poznanie takiego prawa, które jest stabilne. W odniesieniu do prawa związanego z funkcjonowaniem szkoły stabilność jest szczególnie istotna. Nie tylko pozwala na planowanie pewnych działań bez obawy o zmianę obowiązujących w danym zakresie regulacji prawnych, ale umożliwia koncentrację na realizacji zadań dydaktycznych i wychowawczo-opiekuńczych. Tymczasem w zakresie przepisów prawa oświatowego z pewnością trudno mówić o stabilności. Podstawowa dla funkcjonowania szkoły Ustawa z dnia 7 września 1991 r. o systemie oświaty, od momentu jej uchwalenia do dnia, w którym piszę ten artykuł, zmieniła się 69 razy (w tym 31 razy na mocy ustaw zmieniających ustawę o systemie oświaty), co oznacza, że średnio zmieniała się więcej niż trzy razy rocznie. Odnotowałam jednak lata, w których zmieniła się sześć razy, np. w 2005 r. i 2007 r.

Spośród uchwalonych ustaw zmieniających omawiany akt prawny 12 odnosiło się do sprawowania nadzoru pedagogicznego, co oznacza, że ponad $1 / 3$ ustaw zmieniających (31) dotyczyła także tego zagadnienia. W rezultacie możemy

${ }^{1} \mathrm{Z}$ dysfunkcjonalnością prawa mamy do czynienia wówczas, gdy prawny system normatywny charakteryzuje się niewielką zdolnością przystosowawczą do potrzeb społecznych, co może mieć wpływ także na rozwój gospodarki czy procesy demokratyzacji stosunków politycznych (Kojder, 1995, s. 254). 
wymienić lata, w których nie było zmian ustawowych w zakresie nadzoru pedagogicznego - są to lata 1992, 1993, 1996, 1997, 1999, 2005, 2006, 2010, 2011, 2012 (tab. 1). Należy dodać, że od 1991 r., czyli od momentu uchwalenia ustawy o systemie oświaty wydanych zostało dziewięć rozporządzeń Ministra Edukacji Narodowej lub zmian do obowiązujących rozporządzeńn ${ }^{2}$, regulujących szczegółowo kwestię nadzoru pedagogicznego ${ }^{3}$. Na podstawie tabeli 1 widzimy, że tylko sześć lat po $1991 \mathrm{r}$. było wolnych od zmian w tym zakresie. Są to lata 1992, 1994, 1996, 2010, 2011, 2012. Taki stan rzeczy potwierdza brak stabilności prawa w zakresie nadzoru pedagogicznego. Nie oznacza to rzecz jasna, że wszystkie spośród wymienionych zmian miały charakter diametralny. Jedne - były bardziej zasadnicze, inne - drobne. Niemniej jednak zmiany te następowały, a to z pewnością nie sprzyja stabilizacji w tym zakresie.

Tabela 1. Zmiany prawne w zakresie nadzoru pedagogicznego w szkołach

\begin{tabular}{|c|c|c|}
\hline Rok & $\begin{array}{c}\text { Zmiana wynikająca z ustawy } \\
\text { o zmianie ustawy o systemie oświaty } \\
\text { (adresy publikacyjne) }\end{array}$ & $\begin{array}{c}\text { Rozporządzenie ministra właściwego } \\
\text { do spraw oświaty lub zmiana } \\
\text { do obowiązującego rozporządzenia } \\
\text { (adresy publikacyjne) }\end{array}$ \\
\hline 1992 & \multirow{2}{*}{\multicolumn{2}{|c|}{ Brak zmian }} \\
\hline 1993 & & \\
\hline 1994 & Dz.U. 1994 Nr 53, poz. 215 & Dz.U. 1994 Nr 28, poz. 100 \\
\hline 1995 & Dz.U. 1995 Nr 101, poz. 504 & \\
\hline 1996 & \multicolumn{2}{|l|}{ Brak zmian } \\
\hline 1997 & & Dz.U. 1997 Nr 9, poz. 46 \\
\hline 1998 & Dz.U. 1998 Nr 117, poz. 759 & \\
\hline 1999 & & Dz.U. 1999 Nr 67, poz. 759 \\
\hline 2000 & Dz.U. 2000 Nr 122, poz. 1320 & Dz.U. 2000 Nr 83, poz. 943 \\
\hline 2001 & Dz.U. 2001 Nr 111, poz. 1194 & \\
\hline 2002 & $\begin{array}{l}\text { Dz.U. } 2002 \mathrm{Nr} 41 \text {, poz. } 362 \\
\text { Dz.U. } 2002 \mathrm{Nr} 141 \text {, poz. } 1185\end{array}$ & \\
\hline
\end{tabular}

${ }^{2}$ Prawie każdy z tych aktów prawnych został wydany przez innego ministra (wyjątek stanowią dwa rozporządzenia z 19997 i 1999 r.).

${ }^{3}$ Biorę tu pod uwage jedynie rozporządzenia dotyczące nadzoru pedagogicznego wydawane przez ministrów właściwych do spraw oświaty. 
Tabela 1 - cd.

\begin{tabular}{|c|c|c|}
\hline Rok & $\begin{array}{c}\text { Zmiana wynikająca z ustawy } \\
\text { o zmianie ustawy o systemie oświaty } \\
\text { (adresy publikacyjne) }\end{array}$ & $\begin{array}{c}\text { Rozporządzenie ministra właściwego } \\
\text { do spraw oświaty lub zmiana } \\
\text { do obowiązującego rozporządzenia } \\
\text { (adresy publikacyjne) }\end{array}$ \\
\hline 2003 & Dz.U. 2003 Nr 137, poz. 1304 & \\
\hline 2004 & Dz.U. 2004 Nr 162, poz. 1690 & Dz.U. $2004 \mathrm{Nr}$ 89, poz. 845 \\
\hline 2005 & & Dz.U. $2005 \mathrm{Nr}$ 41, poz. 386 \\
\hline 2006 & & Dz.U. 2006 Nr 235, poz. 1703 \\
\hline 2007 & Dz.U. 2007 Nr 181, poz. 1292 & \\
\hline 2008 & Dz.U. 2008 Nr 145, poz. 917 & \\
\hline 2009 & Dz.U. 2009 Nr 56, poz. 458 & Dz.U. 2009 Nr 168, poz. 1324 \\
\hline 2010 & \multirow{3}{*}{\multicolumn{2}{|c|}{ Brak zmian }} \\
\hline 2011 & & \\
\hline 2012 & & \\
\hline
\end{tabular}

Warto jednak podkreślić pewną stabilizację utrzymująca się w ostatnich latach po wydaniu Rozporządzenia Ministra Edukacji Narodowej z dnia 7 października 2009 r. w sprawie nadzoru pedagogicznego (Dz.U. 2009 Nr 168, poz. 1324). Trzyletni okres bez żadnych zmian w tym zakresie nie zdarzył się jeszcze od początku obowiązywania ustawy o systemie oświaty.

\section{Eksplozja prawa w dziedzinie nadzoru pedagogicznego}

Cechą charakterystyczną współczesnego świata jest rozrost przepisów prawnych. Habermas wyjaśnia to na gruncie teorii krytycznej. Jego zdaniem tzw. jurydyzacja jest częścią „kolonizacji” świata (Habermas, 2002, s. 439), która oznacza podporządkowanie działan komunikacyjnych systemowi polityczno-administracyjnemu i gospodarczemu.

Innej interpretacji dokonuje Friedman, który eksplozję prawa określa mianem legalizmu. Jego zdaniem, zjawisko to polega nie tylko na wzroście liczby regulacji prawnych oraz poszerzaniu się ich zakresu, ale również triumfie procedury, której obecność zauważamy w różnych obszarach naszego funkcjonowania (Friedman, 1993, s. 16). Zdaniem Friedmana rozrost przepisów prawnych 
nie jest niczym zaskakującym nie tylko w kontekście wzrastającej złożoności świata, ale również $-\mathrm{z}$ punktu widzenia realizacji zasady indywidualnego wyboru. Istnienie wielu regulacji prawnych jest, jego zdaniem, konieczne po to, by chronić i urzeczywistniać indywidualny wybór (Friedman, 1993, s. 72, 209-210). Należy jednak zauważyć, że interpretacje Friedmana odnoszą się do społeczeństw zachodnich, charakteryzujących się silnie zakorzenionym indywidualizmem w sferze kultury prawnej. W przypadku polskiej kultury prawnej należy zwrócić uwagę na jej specyfikę. Transformacja ustrojowa w naszym kraju spowodowała, że w krótkim czasie należało „wprowadzić” szereg nowych regulacji prawnych. Pośpiech nigdy nie służy jakości, ale nie to chyba było największym problemem. Jak pisze Czarnota, jedną z istotnych kwestii była metoda transformacji, która doprowadziła do powstania tzw. sytemu hybrydowego, co oznacza istnienie typowych dla demokracji instytucji, ale funkcjonujących według niedemokratycznych zasad (Czarnota, 2006, s. 18-21). Owa „hybryda” ma również przełożenie na system prawny i w moim przekonaniu dotyczy celów tworzenia prawa. Dlatego też tzw. eksplozji prawa nie traktowałabym za Friedmanem jako zabezpieczenia realizacji zasady wolnego wyboru, ale raczej w kategoriach dysfunkcjonalności prawa. Mając na uwadze globalne tendencje w zakresie wzrostu liczby przepisów i obszarów regulowanych przez prawo, należy uwzględnić specyfikę polską łączącą się z określonymi cechami tego prawa, jak wspominany wyżej brak stabilności prawa czy też niespójność w kwestii celów deklarowanych przez prawo oraz tych, które de facto wynikają z wykładni aktów prawnych lub są realizowane. Eksplozja prawa, zwłaszcza prawa wątpliwej jakości, nie jest zatem ani neutralną, ani - tym bardziej - pozytywną cechą kultury prawnej.

Od początku obowiązywania ustawy o systemie oświaty mamy do czynienia ze swego rodzaju schematem, jeśli chodzi o rodzaje i liczbę aktów prawnych regulujących ten zakres. Podstawy dotyczące funkcjonowania nadzoru zostały umieszczone w ustawie o systemie oświaty, zaś szczegóły - w rozporządzeniu ministra właściwego do spraw oświaty ${ }^{4}$. Oznacza to, że regulacje prawne są zasadniczo zawarte w dwóch aktach prawnych. W zakresie liczby aktów prawnych regulujących funkcjonowanie nadzoru pedagogicznego utrzymuje się zatem stały poziom. Inaczej sprawa wygląda w przypadku liczby przepisów prawnych odnoszących się do interesującej nas tematyki. Nie chodzi jednak tylko o liczbę regulacji prawnych, ale o ich zakres przedmiotowy oraz szczegóło-

\footnotetext{
${ }^{4}$ Oddzielne regulacje występują mogą występować w odniesieniu do szkół artystycznych tworzonych i prowadzonych przez ministra właściwego do spraw kultury.
} 
wość. W przypadku zatem Ustawy z dnia 7 września 1991 r. o systemie oświaty $^{5}$ (Dz.U. $1991 \mathrm{Nr} 95$, poz. 425) - cztery zasadnicze artykuły odnoszące się do nadzoru pedagogicznego (art. 33-35 i 39) znacznie się rozrosły, a ponadto dodano jeszcze siedem innych (art. 32a, 32b, 34a-34c, 35a, 35b) ${ }^{6}$. Zmiany, które pojawiały się stopniowo, dotyczyły przede wszystkim dwóch kwestii: kompetencji organów nadzoru pedagogicznego oraz konsekwencji wynikających z niedostatecznych wyników nadzoru ${ }^{7}$. W tym pierwszym przypadku przepisy stały się bardziej precyzyjne, choć należy również zauważyć, iż niektóre z tych zmian wiązały się ze zmianami w zakresie systemu szkolnictwa. Jeśli natomiast chodzi o konsekwencje wynikające z niedostatecznych wyników nadzoru, to oprócz zmian merytorycznych, charakterystyczny w tym przypadku jest wzrost proceduralizacji w tym zakresie (tab. 2).

Tabela 2. Zestawienie kształtu regulacji prawnych dotyczących konsekwencji wynikających z niedostatecznych wyników nadzoru pedagogicznego na podstawie art. 33 i 34 Ustawy z dnia 7 września 1991 r. o systemie oświaty

\begin{tabular}{|c|c|}
\hline Pierwotny kształt regulacji prawnych ${ }^{*}$ & Obecny kształt regulacji prawnych ${ }^{* *}$ \\
\hline $\begin{array}{l}\text { Możliwość wydawania przez organy sprawujące } \\
\text { nadzór pedagogiczny zaleceń wynikających z czyn- } \\
\text { ności nadzoru w zakresie oceny stanu i warunków } \\
\text { działalności dydaktycznej wychowawczej i opiekuń- } \\
\text { czej oraz w zakresie analizy i oceny efektów realizacji } \\
\text { programów nauczania i zadań statutowych. }\end{array}$ & $\begin{array}{l}\text { Możliwość wydawania przez nauczycieli wykonują- } \\
\text { cych czynności z zakresu nadzoru pedagogicznego } \\
\text { zaleceń, uwag i wniosków wynikających z prze- } \\
\text { prowadzonych czynności. A jeżeli są to istotne } \\
\text { uchybienia - dodatkowo poinformowanie o tym } \\
\text { przez organ nadzoru pedagogicznego organu pro- } \\
\text { wadzący szkołę. } \\
\text { Dyrektor szkoły w ciągu } 7 \text { dni od otrzymania za- } \\
\text { leceń, uwag i wniosków może zgłosić wobec nich } \\
\text { zastrzeżenia do organu sprawującego nadzór peda- } \\
\text { gogiczny. } \\
\text { Jeżeli organ nie uwzględni zastrzeżeń, dyrektor } \\
\text { szkoły lub placówki jest obowiązany powiadomić } \\
\text { ten organ o realizacji zaleceń, uwag i wniosków } \\
\text { w terminie } 30 \text { dni. }\end{array}$ \\
\hline
\end{tabular}

${ }^{5}$ Dz.U. 1991 Nr 95, poz. 425

${ }^{6}$ Por. na podstawie obecnego stanu prawnego Ustawy z dnia 7 września 1991 r. o systemie oświaty (Dz.U. $2004 \mathrm{Nr}$ 256, poz. 2572 ze zmianami).

${ }^{7}$ Należy także zauważyć, że w 1995 r. na mocy ustawy zmieniającej zmienił się także zasadniczy - dla określenia, na czym polega nadzór pedagogiczny - art. 33 ustawy o systemie oświaty. 
Tabela 2 - cd.

\begin{tabular}{|c|c|}
\hline Pierwotny kształt regulacji prawnych* & Obecny kształt regulacji prawnych ${ }^{* *}$ \\
\hline & $\begin{array}{l}\text { Organ sprawujący nadzór pedagogiczny może wy- } \\
\text { dawać organowi prowadzącemu szkołę zalecenia } \\
\text { wynikające z czynności nadzoru. Organ prowadzą- } \\
\text { cy szkołę może zgłosić zastrzeżenia do tych zale- } \\
\text { ceń w ciągu } 7 \text { dni. Jeżeli zastrzeżenia nie zostaną } \\
\text { uwzględnione, organ prowadzący szkołę musi jest } \\
\text { obowiązany powiadomić organ prowadzący nadzór } \\
\text { o realizacji tych zaleceń w ciągu } 30 \text { dni. }\end{array}$ \\
\hline $\begin{array}{l}\text { Możliwość wydawania przez organy nadzoru peda- } \\
\text { gogicznego poleceń (w formie decyzji) usunięcia } \\
\text { nieprawidłowości (tu: rozumianych jako nieprze- } \\
\text { strzeganie przepisów ustawy) w wyznaczonym } \\
\text { terminie. }\end{array}$ & $\begin{array}{l}\text { Możliwość wydawania przez organy nadzoru peda- } \\
\text { gogicznego poleceń (w formie decyzji) usunięcia } \\
\text { nieprawidłowości (tu: rozumianych jako nieprze- } \\
\text { strzeganie przepisów ustawy) w wyznaczonym } \\
\text { terminie, chyba że naruszenie przepisów ustawy } \\
\text { nastąpiło w uchwale organu jednostki samorządu } \\
\text { terytorialnego (w tym przypadku kurator oświaty jest } \\
\text { obowiązany powiadomić wojewodę o naruszeniu } \\
\text { przepisów ustawy). } \\
\text { W przypadku stwierdzenia niedostatecznych efek- } \\
\text { tów kształcenia lub wychowania w szkole organ } \\
\text { sprawujący nadzór pedagogiczny poleca dyrektoro- } \\
\text { wi szkoły opracowanie, w uzgodnieniu z organem } \\
\text { prowadzącym, programu i harmonogramu po- } \\
\text { prawy efektywności kształcenia lub wychowania. } \\
\text { Wdrożenie programu następuje w terminach } \\
\text { określonych w harmonogramie, zaakceptowa- } \\
\text { nych przez organ sprawujący nadzór pedagogiczny. } \\
\text { Program musi uwzględnić uwagi i wnioski zgłoszone } \\
\text { przez organ sprawujący nadzór pedagogiczny. }\end{array}$ \\
\hline $\begin{array}{l}\text { Możliwość postawienia szkoły w stan likwidacji } \\
\text { w przypadku niewykonania powyższych poleceń. } \\
\text { Możliwość przejęcia szkoły podstawowej "gmin- } \\
\text { nej" do prowadzenia przez kuratora oświaty do } \\
\text { czasu usunięcia uchybień }\end{array}$ & $\begin{array}{l}\text { Wystąpienie przez organ sprawujący nadzór peda- } \\
\text { gogiczny do organu prowadzącego szkołę z wnio- } \\
\text { skiem o odwołanie dyrektora szkoły z końcem albo } \\
\text { w czasie roku szkolnego bez wypowiedzenia (jeżeli } \\
\text { dyrektor nie usunie uchybień w wyznaczonych ter- } \\
\text { minach, nie opracuje lub nie wdroży w określonych } \\
\text { w harmonogramie terminach programu poprawy } \\
\text { efektywności kształcenia lub wychowania) Wniosek } \\
\text { w tej sprawie jest wiążący dla organu prowadzą- } \\
\text { cego szkołę. }\end{array}$ \\
\hline
\end{tabular}


Tabela 2 - cd.

\begin{tabular}{|l|l|}
\hline Pierwotny kształt regulacji prawnych* & \multicolumn{1}{|c|}{ Obecny kształt regulacji prawnych $^{* *}$} \\
\hline & $\begin{array}{l}\text { Zawiadomienie właściwego wojewody, w przy- } \\
\text { padku gdy szkoła prowadzona przez jednostkę samo- } \\
\text { rządu terytorialnego, a także sama jednostka samo- } \\
\text { rządu terytorialnego, nie usunie uchybień wynikłych } \\
\text { z naruszenia przepisów ustawy. } \\
\text { Możliwość cofnięcia, w drodze decyzji, zezwolenia } \\
\text { na założenie szkoły prowadzonej przez osobę } \\
\text { fizyczna lub prawną (z wyjątkiem jednostki samo- } \\
\text { rządu terytorialnego), jeżeli dyrektor nie usunie uchy- } \\
\text { bień w wyznaczonych terminach, nie opracuje lub nie } \\
\text { wdroży w określonych w harmonogramie terminach } \\
\text { programu poprawy efektywności kształcenia lub wy- } \\
\text { chowania. } \\
\text { Cofnięcie zezwolenia na założenie szkoły jest rów- } \\
\text { noznaczne z postawieniem jej w stan likwidacji. }\end{array}$ \\
& \\
\hline
\end{tabular}

* Ustawa z dnia 7 września 1991 r. o systemie oświaty (Dz.U. $1991 \mathrm{Nr}$ 95, poz. 425).

** Ustawa z dnia 7 września 1991 r. o systemie oświaty (Dz.U. 2004 Nr 256, poz. 2572 ze zmianami).

Tabela 2 pokazuje, jak bardzo zmieniły się, a zarazem rozbudowały przepisy prawne w tym zakresie. Mamy tu do czynienia ze znacznym wzrostem nasycenia tego obszaru regulacjami prawnymi. W obecnym stanie prawnym pojawiają się różne możliwości postępowania zależne od rodzaju uchybień oraz organów prowadzących szkołę. Charakterystyczny jest również schemat procedury wskazujący na możliwości działania poszczególnych podmiotów, terminy, a także konsekwencje podjęcia określonych decyzji, co w rezultacie tworzy określone ,ścieżki działania" funkcjonujące w ramach warunku: „jeżeli - to". Warto również zauważyć, że w pierwotnym kształcie ustawy o systemie oświaty regulacje prawne dotyczące konsekwencji wynikających z niedostatecznych wyników nadzoru pedagogicznego miały wyłącznie charakter fakultatywny. To organ nadzoru pedagogicznego decydował o podjęciu lub nie określonego działania. W obecnym stanie prawnym wygląda to nieco inaczej. Kompetencje są zróżnicowane. Obok tych fakultatywnych pojawiają się również obligatoryjne, czyli takie, które zobowiązują organ do określo- 
nego działania w przypadku zaistnienia konkretnej sytuacji ${ }^{8}$. Należy jednak podkreślić wspominaną już stabilizację w zakresie nadzoru pedagogicznego w ostatnich trzech latach.

Nieco inaczej sprawa wygląda w przypadku zmian prawnych w nadzorze pedagogicznym na poziomie rozporządzeń wydawanych przez ministrów właściwych do spraw oświaty. Należy podkreślić, że w tym przypadku mowa jest o nowych rozporządzeniach wydawanych przez kolejnych ministrów, a nie o zmianach do jednego obowiązującego aktu prawnego, jak było w przypadku ustawy o systemie oświaty. Porównując pierwsze i ostanie z wydanych na podstawie ustawy o systemie oświaty rozporządzeń, rzeczywiście zauważamy wzrost liczby regulacji prawnych w tym zakresie (z 11 paragrafów w 1991 roku do 27 paragrafów w 2009 r. $^{10}$ ). Wykres 1 przedstawia jednak, jak wyglądała sytuacja $\mathrm{w}$ tym zakresie na przestrzeni poszczególnych lat.

Z pewnością nie mamy tu do czynienia ze stałym wzrostem. „Wyróżniają się" tu pod względem liczby przepisów rozporządzenia z 1996 r. ${ }^{11}$ i obecnie obowiązujące z 2009 r. W uzupełnieniu do wykresu 1 należy dodać, że rozporządzenie z 2004 r. ${ }^{12}$ jest dodatkowo wyposażone w załącznik - „Standardy oceny jakości pracy szkół i placówek", co w rezultacie zasadniczo zmienia poziom szczegółowości i obszerności tego aktu. Podobnie sytuacja wygląda w przypadku rozporządzenia z $2009 \mathrm{r}$.

Obszerna analiza poszczególnych rozporządzeń, której kryteria stanowiły: liczba przepisów prawnych, ich zakres, szczegółowość, stopień proceduralizacji działań regulowanych tymi przepisami, doprowadziły mnie do następujących wniosków:

\footnotetext{
${ }^{8}$ Zob. tabela 2 - wniosek o odwołanie dyrektora, zawiadomienie wojewody.

${ }^{9}$ Rozporządzenie Ministra Edukacji Narodowej z dnia 10 grudnia 1991 r. w sprawie szczegółowych zasad sprawowania nadzoru pedagogicznego, wykazu stanowisk i kwalifikacji niezbędnych do ich zajmowania oraz zasad i trybu dokonywania oceny pracy nauczyciela (Dz.U. $1991 \mathrm{Nr}$ 122, poz. 537).

${ }^{10}$ Rozporządzenie Ministra Edukacji Narodowej z dnia 7 października 2009 r. w sprawie nadzoru pedagogicznego (Dz.U. $2009 \mathrm{Nr}$ 168, poz. 1324).

${ }^{11}$ Rozporządzenie Ministra Edukacji Narodowej z dnia 31 grudnia 1996 r. w sprawie szczegółowych zasad sprawowania nadzoru pedagogicznego, wykazu stanowisk i kwalifikacji niezbędnych do ich zajmowania (Dz.U. 1997 Nr 9 poz. 46).

${ }^{12}$ Rozporządzenie Ministra Edukacji Narodowej i Sportu z dnia 23 kwietnia 2004 r. w sprawie szczegółowych zasad sprawowania nadzoru pedagogicznego, wykazu stanowisk wymagających kwalifikacji pedagogicznych, kwalifikacji niezbędnych do sprawowania nadzoru pedagogicznego, a także kwalifikacji osób, którym można zlecać prowadzenie badań i opracowywanie ekspertyz (Dz.U. 2004 Nr 89, poz. 845).
} 
1. Obecnie obowiązujące regulacje prawne (Rozporządzenie Ministra Edukacji Narodowej z dnia 7 października 2009 r. w sprawie nadzoru pedagogicznego, Dz.U. 2009 Nr 168, poz. 1324) wykazują najwyższy poziom proceduralizacji spośród różnych rozwiązań, które pojawiły się od $1991 \mathrm{r}$. Dotyczy to dwóch form nadzoru pedagogicznego: ewaluacji zewnętrznej i kontroli. Rozporządzenie precyzuje szczegółowo działania podejmowane przez określone organy, terminy wykonywania tych działań, warunki formalne, jakie muszą zostać spełnione zarówno w przypadku osób, które przeprowadzają te działania, jak i dokumentacji związanej z nadzorem pedagogicznym. Dodatkowo określa również tryb postępowania w przypadku pojawienia się zastrzeżeń do raportu z przeprowadzonej ewaluacji czy protokołu kontroli. Wyznacza także szczegółowo obszary ewaluacji, wyróżniając $w$ ich ramach poszczególne wymaganie oraz charakteryzując podstawowy i wysoki stopień spełniania danego wymagania.

Wykres 1. Liczba regulacji prawnych na poziomie rozporządzeń wydanych przez ministra właściwego do spraw oświaty w zakresie nadzoru pedagogicznego

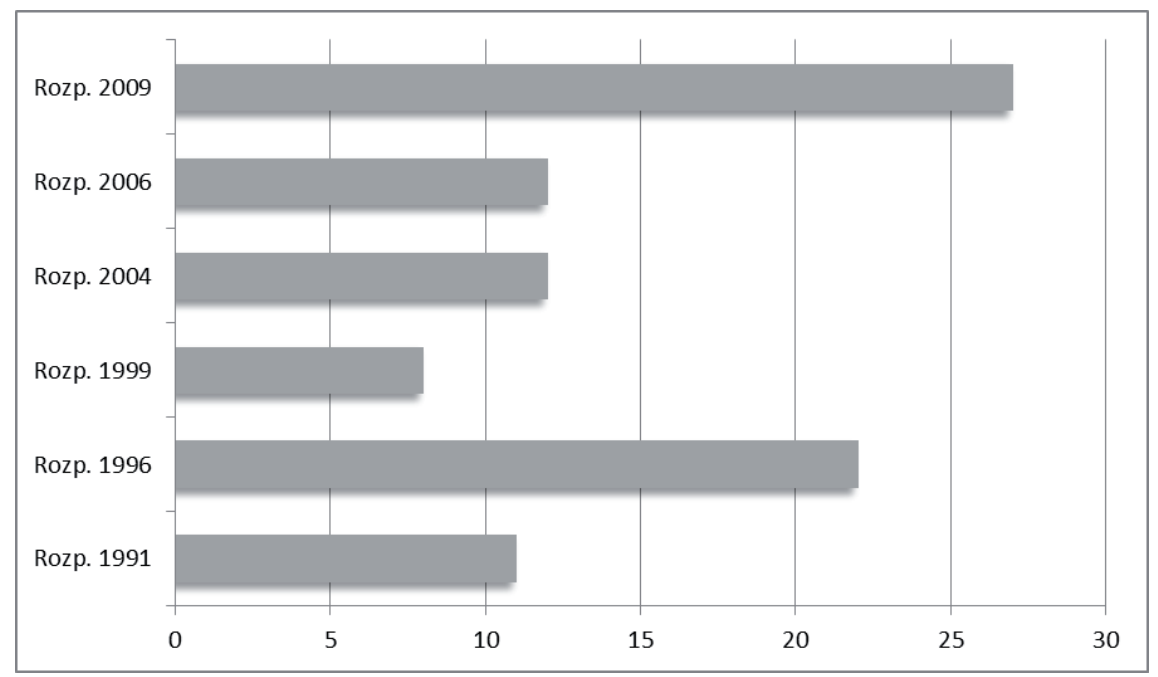

2. W przypadku regulacji prawnych zawartych w rozporządzeniach dotyczących nadzoru pedagogicznego należy zauważyć, że choć w rezultacie nastąpił wzrost w zakresie proceduralizacji i szczegółowości tych przepisów, to jednak w ramach poszczególnych rozporządzeń mamy do czynienia z „falowaniem”. Pierwsze rozporządzenie wykonawcze w zakresie 
nadzoru pedagogicznego, które zostało wydane na podstawie delegacji ustawowej zawartej $\mathrm{w}$ ustawie o systemie oświaty ${ }^{13}$ operowało rzeczywiście na najwyższym poziomie ogólności. W kolejnym - z 1996 r. $^{14}$ z pewnością mieliśmy do czynienia ze wzrostem szczegółowości i proceduralizacji przepisów. Cele oraz działania podejmowane w ramach nadzoru pedagogicznego miały charakter bardziej precyzyjny w porównaniu z poprzednim stanem prawnym. Pojawiły się ponadto przepisy dotyczące organizacji nadzoru pedagogicznego ze strony kuratorium oświaty. Jeśli chodzi natomiast o wzrost proceduralizacji, charakterystyczna była rozbudowana procedura wizytacji, a także regulacje związane $\mathrm{z}$ dokumentowaniem hospitacji i wizytacji oraz odnoszące się do nowego dokumentu - planu nadzoru - sporządzanego przez dyrektora szkoły. Następne rozporządzenie z $1999 \mathrm{r} .{ }^{15}$ to wyraźny spadek stopnia proceduralizacji działań z zakresu nadzoru pedagogicznego. Omawiany akt prawny koncentruje się na nowej formie nadzoru - mierzeniu jakości pracy szkół i choć zadania kuratora oświaty i dyrektora szkoły zostały tu określone dość precyzyjnie, to jednak nie stanowi szczegółowych procedur w zakresie działań związanych z nadzorem pedagogicznym. W kolejnym rozporządzeniu - z $2004 \mathrm{r}^{16}{ }^{16}$ - następuje ponowny wzrost szczegółowości regulacji prawnych. Dotyczy to wspominanego już mierzenia jakości pracy szkół, a zwłaszcza diagnozy i oceny stopnia spełniania przez szkoły standardów w zakresie: koncepcji pracy szkoły, zarządzania i organizacji, kształcenia, wychowania i opieki.

Każdy z tych zakresów podzielono na obszary, a w ramach poszczególnych obszarów zostały opisane standardy i podane przykładowe jego

\footnotetext{
${ }^{13}$ Rozporządzenie Ministra Edukacji Narodowej z dnia 10 grudnia 1991 r. w sprawie szczegółowych zasad sprawowania nadzoru pedagogicznego, wykazu stanowisk i kwalifikacji niezbędnych do ich zajmowania oraz zasad i trybu dokonywania oceny pracy nauczyciela (Dz.U. $1991 \mathrm{Nr}$ 122, poz. 537).

${ }^{14}$ Rozporządzenie Ministra Edukacji Narodowej z dnia 31 grudnia 1996 r. w sprawie szczegółowych zasad sprawowania nadzoru pedagogicznego, wykazu stanowisk i kwalifikacji niezbędnych do ich zajmowania (Dz.U. $1997 \mathrm{Nr}$ 9, poz. 46).

${ }^{15}$ Rozporządzenie Ministra Edukacji Narodowej z dnia 13 sierpnia 1999 r. w sprawie szczegółowych zasad sprawowania nadzoru pedagogicznego, a także kwalifikacji osób, którym można zlecać prowadzenie badań i opracowywanie ekspertyz (Dz.U. $1999 \mathrm{Nr} 67$, poz. 759).

${ }^{16}$ Rozporządzenie Ministra Edukacji Narodowej i Sportu z dnia 23 kwietnia 2004 r. w sprawie szczegółowych zasad sprawowania nadzoru pedagogicznego, wykazu stanowisk wymagających kwalifikacji pedagogicznych, kwalifikacji niezbędnych do sprawowania nadzoru pedagogicznego, a także kwalifikacji osób, którym można zlecać prowadzenie badań i opracowywanie ekspertyz (Dz.U. 2004 Nr 89, poz. 845).
} 
wskaźniki. Stopień szczegółowości tego aktu prawnego jest porównywalny do obecnie obowiązującego rozporządzenia z 2009 r., jednakże wykazuje ono dużo mniejszy stopień proceduralizacji. Następne rozporządzenie $-\mathrm{z} 2006 \mathrm{r} .^{17}$ - przyniosło w zasadzie powrót do rozwiązań z $1996 \mathrm{r}$., co oznaczało de facto zmniejszenie stopnia szczegółowości przepisów. Spadek ten nie był jednak tak znaczący, jak w 1999 r., choć zmiana była istotna merytorycznie. W ten sposób doszliśmy do ostatniego w tym zakresie aktu prawnego - rozporządzenia z 2009 r. ${ }^{18}$, w którym następuje ponownie duży wzrost zarówno w zakresie szczegółowości przepisów, jaki i proceduralizacji działań związanych z nadzorem pedagogicznym.

3. Mimo częstych zmian, również merytorycznych (np. odnoszących się do katalogu form nadzoru pedagogicznego), zakres przedmiotowy regulacji prawnych w tym zakresie pozostaje na względnie stałym poziomie. Analizując cele i działania realizowane w ramach nadzoru pedagogicznego, a wyartykułowane na poziomie rozporządzeń, można zauważyć, że w obecnym stanie prawnym brakuje dwóch standardowych zadań, które dotychczas były wymieniane: udziału w rozwiązywaniu bieżących problemów dydaktycznych, wychowawczych i opiekuńczych oraz przekazywania informacji o aktualnych problemach oświatowych i obowiązujących przepisach. Nie twierdzę, że zadania te nie są spełniane, a jedynie to, że po raz pierwszy nie zostały wyartykułowane. Pojawiło się za to nowe zadanie, związane ze zmianą postrzegania charakteru instytucji jaką jest szkoła - podawanie do publicznej wiadomości wyników nadzoru pedagogicznego. Współczesna szkoła coraz bardziej podlega prawom rynku, a zatem rywalizacja, czy - używając języka „rynku” - konkurencja jest w tym wypadku nieodłącznym elementem.

Mimo braku istotnych zmian w zakresie przedmiotowym, należy podkreślić, iż omawiany wyżej wzrost stopnia szczegółowości i proceduralizacji regulacji prawnych wpłynął na charakter nadzoru pedagogicznego. Formalizacja działań o charakterze opiekuńczo-wychowawczym w związku z działaniami z zakresu nadzoru pedagogicznego powoduje nieuchronnie niebezpieczeństwo pojawienia się działań pozornych, fasadowych. Takich wniosków dostarcza zwłaszcza

\footnotetext{
${ }^{17}$ Rozporządzenie Ministra Edukacji Narodowej z dnia 15 grudnia 2006 r. w sprawie szczegółowych zasad sprawowania nadzoru pedagogicznego, wykazu stanowisk wymagających kwalifikacji pedagogicznych, kwalifikacji osób, którym można zlecać prowadzenie badań i opracowywanie ekspertyz (Dz.U. 2006 Nr, 235 poz. 1703).

${ }^{18}$ Rozporządzenie Ministra Edukacji Narodowej z dnia 7 października 2009 r. w sprawie nadzoru pedagogicznego (Dz.U. $2009 \mathrm{Nr}$ 168, poz. 1324).
} 
lektura załączników do rozporządzenia z 2009 r., określających wymagania, jakie powinna spełnić szkoła, aby uzyskać określoną ocenę (A-D).

\section{Spójność regulacji prawnych, czyli czym tak naprawdę jest nadzór pedagogiczny?}

Całościowe spojrzenie na nadzór pedagogiczny, jego konstrukcję i wykładnię przepisów w tym zakresie wskazuje na istotną rozbieżność pomiędzy tym, co jest deklarowane, a tym, co faktycznie wynika z owych regulacji. Sprawa jest poważna, ponieważ owa niespójność dotyczy istoty nadzoru pedagogicznego.

Zgodnie $\mathrm{z}$ art. 33 ust. 1 ustawy o systemie oświaty ${ }^{19}$ nadzór pedagogiczny polega na:

- ocenianiu stanu i warunków działalności dydaktycznej, wychowawczej i opiekuńczej szkół, placówek i nauczycieli;

- analizowaniu i ocenianiu efektów działalności dydaktycznej, wychowawczej i opiekuńczej oraz innej działalności statutowej szkół i placówek;

- udzielaniu pomocy szkołom, placówkom i nauczycielom w wykonywaniu ich zadań dydaktycznych, wychowawczych i opiekuńczych;

- inspirowaniu nauczycieli do innowacji pedagogicznych, metodycznych i organizacyjnych.

$\mathrm{Na}$ podstawie tej regulacji prawnej wnioskujemy o dwóch zasadniczych kierunkach działalności związanej z nadzorem pedagogicznym. Pierwszy dotyczy analizy i oceny działalności dydaktycznej, wychowawczej i opiekuńczej (oraz innej statutowej) zarówno na „wejściu”, jak i „wyjściu”. Drugi natomiast odnosi się do wspierania szkół w wykonywanych przez nich zadaniach z tego zakresu. Obecność drugiego kierunku działalności związanej z nadzorem pedagogicznym oznacza, że ustawodawca dostrzega specyfikę tego nadzoru ${ }^{20}$. Szczegółowe warunki, tryb oraz formy nadzoru pedagogicznego są natomiast regulowane przepisami wspominanego już Rozporządzenia Ministra Edukacji

${ }^{19}$ Ustawa z dnia 7 września 1991 r. o systemie oświaty (Dz.U. 2004 Nr 256, poz. 2572 ze zmianami).

${ }^{20}$ Nadzór jest pojęciem z zakresu prawa administracyjnego i oprócz kontroli obejmuje kompetencję do władczego rozstrzygania i podejmowania decyzji przez organ nadzorujący. Nadzór jest zatem pojęciem ściśle związanym z hierarchicznością organów administracji i jednoznacznie przesądza o tym, że mamy do czynienia z kulturą władzy. Nie można oczekiwać, że w przypadku szkoły będzie inaczej, choć pewne nadzieje daje przymiotnik ,„pedagogiczny”. Oznacza to, że mówiąc o nadzorze pedagogicznym, mamy na myśli tę część kontroli i uprawnień władczych, która dotyczy działalności pedagogicznej szkoły (a nie administracyjno-finansowej). 
Narodowej z dnia 7 października 2009 r. w sprawie nadzoru pedagogicznego ${ }^{21}$, wydanymi na podstawie delegacji ustawowej z art. 35 ust. 6 ustawy o systemie oświaty. Rozporządzenie to wśród form nadzoru pedagogicznego wymienia ewaluację (wewnętrzną, zewnętrzną, całościową, problemową), kontrolę oraz wspomaganie (§ 6). W stosunku do wszystkich form nadzoru pedagogicznego rozporządzenie konstruuje definicje legalne. I tak ewaluacja jest tu określona jako praktyczne badanie oceniające przeprowadzane w szkole lub placówce (§ 2 pkt 4), kontrola - jako działanie organu sprawującego nadzór pedagogiczny prowadzone $\mathrm{w}$ szkole lub placówce $\mathrm{w}$ celu oceny stanu przestrzegania przepisów prawa dotyczących działalności dydaktycznej, wychowawczej i opiekuńczej oraz innej działalności statutowej szkół i placówek (§ 2 pkt 9), natomiast wspomaganie - jako działanie organu sprawującego nadzór pedagogiczny mające na celu inspirowanie i intensyfikowanie w szkołach oraz placówkach procesów służących poprawie i doskonaleniu ich pracy, ukierunkowanych na rozwój uczniów i wychowanków (§ 2 pkt 10). Formy nadzoru wskazane i zdefiniowane $\mathrm{w}$ omawianym rozporządzeniu odpowiadają zatem kierunkom wyznaczanym przez art. 33 ustawy o systemie oświaty. Czy zatem rekonstrukcja kultury prawnej szkoły na podstawie obowiązujących przepisów prawnych w zakresie funkcji organów nadzoru pedagogicznego daje nam podstawy do tego, by nieco „,zmiękczyć” kulturę władzy wynikającą ze specyfiki prawa administracyjnego? Niestety nie. Uzasadnienie takiej odpowiedzi wynika przede wszystkim z całościowej analizy przepisów rozporządzenia w połączeniu z regulacjami zawartymi w ustawie o systemie oświaty. Za typowym rozumieniem pojęcia nadzoru w odniesieniu do nadzoru pedagogicznego przemawia zarówno ilość, jak i jakość regulacji z tym związanych. Wspominane rozporządzenie z 2009 r. wymienia, co prawda, formy nadzoru odpowiadające dwóm zasadniczym jego kierunkom wskazanym przez ustawodawcę, ale w rzeczywistości skupia się jedynie na ewaluacji i kontroli. Wspomaganie zajmuje tu pozycje marginalną, a jakość tych przepisów ( $§ 17$ oraz $\S 20$ ust. 1 pkt 3) pozostawia wiele do życzenia. W rezultacie dwa z czterech przykładów działań mieszczących się w ramach tej formy odnoszą się do ewaluacji i kontroli. Pozostałe dwa natomiast są na tyle ogólne, że stają się wręcz frazesami. Nie twierdzę, że podejmowanie działań służących inspirowaniu i intensyfikowaniu pracy szkół ukierunkowanej na rozwój uczniów wymaga ścisłej i szczegółowej regulacji, ale regulacja w obecnym kształcie to dla mnie czytelny komunikat, co tak na-

${ }^{21}$ Rozporządzenie Ministra Edukacji Narodowej z dnia 7 października 2009 r. w sprawie nadzoru pedagogicznego (Dz.U. $2009 \mathrm{Nr}$ 168, poz. 1324). 
prawdę się liczy. Na podstawie konstrukcji prawnej nadzoru pedagogicznego mogę zatem sformułować wniosek, iż nadzór pedagogiczny jest rozumiany w kategoriach klasycznego nadzoru, a kultura prawna w tym zakresie to kultura władztwa administracyjnego. Wykładnia systemowa przepisów pozwala również stwierdzić, iż wspomaganie jako forma nadzoru pedagogicznego ma charakter marginalny i w żadnym razie nie stanowi równoprawnego kierunku działalności związanej z nadzorem pedagogicznym.

Oznacza to brak spójności pomiędzy artykułowanym rozumieniem nadzoru pedagogicznego a jego rzeczywistą interpretacją wynikającą z wykładni całości regulacji prawnych, które tego dotyczą.

\section{Wnioski}

Analiza regulacji prawnych związanych z nadzorem pedagogicznym pozwoliła na wyodrębnienie następujących cech kultury prawnej szkoły:

1. Regulacje prawne związane $\mathrm{z}$ nadzorem pedagogicznym wykazują brak stabilności. Należy jednak zauważyć, że w ostatnich trzech latach mamy tu do czynienia ze stabilizacją.

2. W obecnym stanie prawnym występuje wysoki stopień nasycenia tej dziedziny regulacjami prawnymi. Nie odzwierciedla tego liczba aktów prawnych, ale - ich obszerność. W porównaniu z przepisami prawnymi wydanymi do 2009 r., obecne regulacje posiadają także najwyższy stopień szczegółowości i proceduralizacji działań związanych z nadzorem. Można to zauważyć przede wszystkim na poziomie rozporządzeń, czyli aktów wydawanych - w tym przypadku - przez ministra właściwego do spraw oświaty.

3. Zakres przedmiotowy regulacji prawnych pozostaje teoretycznie na względnie stałym poziomie. Wzrost szczegółowości i proceduralizacji działań z zakresu nadzoru pedagogicznego de facto zmienia jednak obszar zainteresowania prawa. Wkracza ono w sferę działalności opiekuńczo-wychowawczej szkoły, formułując szczegółowe wymagania i konstruując formalno-prawne oceny odpowiadające określonym stopniom spełniania poszczególnych wymagań.

4. Regulacje prawne związane z nadzorem pedagogicznym wykazują brak spójności co do istoty nadzoru pedagogicznego. Ogromna dysproporcja pomiędzy regulacjami, które odnoszą się do poszczególnych form nadzoru pedagogicznego, potwierdza marginalną pozycję wspomagania, a zaproponowane w rozporządzeniu sposoby wspomagania szkoły 
mają charakter powierzchowny, informacyjny, nawiązujący do ewaluacji i sprawiają wrażenie takich, które zostały spisane bez większego zaangażowania i głębokiej refleksji. Nie oznacza to jednak konieczności proceduralizacji działań w tym zakresie. Wszak wcześniejsze moje uwagi wskazują, że nie jestem zwolennikiem takich rozwiązań. Sytuacja ta wymaga jednak - moim zdaniem - przemyślenia, bo w obecnym kształcie nic nie wnosi. Linia obrony tej regulacji, wskazująca na jej specyfikę/ /charakter determinujący ogólne rozwiązania, nie może w tym przypadku znaleźć właściwego umocowania, bo jako kontrargument można podnieść ministerialną ,nadgorliwość” w zakresie formalnej strony oceniania działalności opiekuńczej i wychowawczej szkoły. W rezultacie otrzymujemy czytelny komunikat, czym jest nadzór pedagogiczny. Obraz ten nie jest spójny z deklaracją ustawową.

Reasumując, przypadek nadzoru pedagogicznego analizowany na podstawie regulacji prawnych wskazuje na poważne symptomy dysfunkcjonalności w zakresie kultury prawnej szkoły, zwłaszcza w tej jej części, która odnosi się do tworzenia prawa. Skutkuje to brakiem stabilności, co wytwarza poczucie tymczasowości oraz uniemożliwia szkole spokojną realizację zadań, zmuszając ją do ciągłych zmian w tym zakresie i do przystosowywania się do nowej rzeczywistości prawnej. W konsekwencji obniża się także autorytet prawa. Lektura poszczególnych rozporządzeń obowiązujących w ciągu 20 lat, niestety, nie pozwala sformułować wniosku dotyczącego konstruktywności kolejnych zmian, zwłaszcza w zakresie proponowanych kolejno form nadzoru i sposobów ich uszczegółowiania. Nieuchronnie pojawia się zatem pytanie o interes szkoły i o jej rolę w tym procesie. Czy prawo ma być konstruowane dla szkoły, czy też mechanizm funkcjonowania szkoły ma się sprowadzać jedynie do obowiązkowego wykonawstwa. Czy chodzi o to, by szkołę wspierać i jej pomagać, czy tylko o to, by ją kontrolować i oceniać? Niewątpliwie wiąże się z tym kolejna cecha kultury prawnej szkoły - wiara w omnipotencję środków prawa pozytywnego, czyli prymat prawa stanowionego, ogromne znaczenie przypisywane prawu jako regulatorowi funkcjonowania szkoły. Stanowi to także wyraz dominacji pozytywizmu prawniczego $\mathrm{w}$ podejściu do prawa i zatracenia aksjologicznych jego podstaw. W rezultacie pojawia się niebezpieczeństwo formalnego przestrzegania prawa bez przekonania o jego merytorycznej słuszności. To - w prostej linii - prowadzi do fasadowości, pozorności, co jest szczególne bolesne wtedy, gdy dotyczy edukacji, wychowania, a więc tych sfer, gdzie zaangażowanie jest ważne i potrzebne, bo inaczej zatraca się sens owych procesów. Dysfunkcyjne regulacje, choć nie są tworzone przez samą szkołę, przekłada- 
ją się bezpośrednio na jej funkcjonowanie, wpływają na zakres emocjonalny i behawioralny, budując określone postawy, przekonania, zachowania nie tylko podmiotów edukacyjnych wobec prawa, ale także społeczeństwa wobec szkoły.

\section{Bibliografia}

Czarnota A. (2006), Dwa wymiary postkomunistycznej transformacji i panowania (złego) prawa. Esej na pograniczu socjologii i teorii prawa, w: Jamróz A., Bożyk S. (red.), $Z$ zagadnień wspótczesnych społeczeństw demokratycznych, Temida 2, Białystok.

Dupret B. (2010), Prawo w naukach społecznych, Oficyna Naukowa, Warszawa.

Friedman L. M. (1993), Republika wyboru. Prawo - autorytet - kultura, przekł. W. Madej, Verba, Warszawa.

Geertz C. (2005), Wiedza lokalna. Dalsze eseje z zakresu antropologii interpretatywnej, przekł. D. Wolska, Wydawnictwo Uniwersytetu Jagiellońskiego, Kraków.

Habermas J. (2002), Teoria działania komunikacyjnego, t. 2, przeł. A. M. Kaniowski, PWN, Warszawa.

Karcz E. (2010), Teoria i praktyka zarządzania oświata i szkoła, Instytut Nauk Pedagogicznych Uniwersytetu Opolskiego, Opole.

Kojder A. (1995), Godność i siła prawa. Szkice socjologiczno-prawne, Oficyna Naukowa, Warszawa.

Olejniczak T., Pielachowski J. (2004), Nadzór pedagogiczny i organizacyjny nad szkołami i placówkami, Wydawnictwo eMPi², Poznań.

Pająk J. (1996), Kultura organizacyjna w oświacie. Teoria - praktyka - stymulacja, Katowice.

Szempruch J. (2001), Nauczyciel w zmieniającej się szkole: funkcjonowanie i rozwój zawodowy, Wydawnictwo Oświatowe FOSZE, Rzeszów.

Szubert W. (1983), Uwagi o kulturze prawnej, w: Naród - kultura - osobowość, Księga poświęcona Profesorowi Józefowi Chałasińskiemu, praca zbiorowa, Zakład Narodowy im. Ossolińskich, Wydawnictwo Polskiej Akademii Nauk, Wrocław-Warszawa-Kraków-Gdańsk-Lódź.

Śliwerski B. (2013), Pozory sprawstwa reform oświatowych w III RP, w: Dudzikowa M., Knasiecka-Falbierska K. (red.), Sprawcy i/lub ofiary działań pozornych $w$ edukacji szkolnej, Oficyna Wydawnicza Impuls, Kraków, 


\section{Akty prawne}

Rozporządzenie Ministra Edukacji Narodowej z dnia 10 grudnia 1991 r. w sprawie szczegółowych zasad sprawowania nadzoru pedagogicznego, wykazu stanowisk i kwalifikacji niezbędnych do ich zajmowania oraz zasad i trybu dokonywania oceny pracy nauczyciela, Dz.U. 1991 Nr 122, poz. 537.

Rozporządzenie Ministra Edukacji Narodowej z dnia 10 lutego 1994 r. zmieniające rozporządzenie w sprawie szczegółowych zasad sprawowania nadzoru pedagogicznego, wykazu stanowisk i kwalifikacji niezbędnych do ich zajmowania oraz zasad i trybu dokonywania ocen pracy nauczyciela, Dz.U. 1994 Nr 28, poz. 100.

Rozporządzenie Ministra Edukacji Narodowej z dnia 31 grudnia 1996 r. w sprawie szczegółowych zasad sprawowania nadzoru pedagogicznego, wykazu stanowisk i kwalifikacji niezbędnych do ich zajmowania, Dz.U. 1997 Nr 9, poz. 46.

Rozporządzenie Ministra Edukacji Narodowej z dnia 13 sierpnia 1999 r. w sprawie szczegółowych zasad sprawowania nadzoru pedagogicznego, a także kwalifikacji osób, którym można zlecać prowadzenie badań i opracowywanie ekspertyz, Dz.U. 1999 Nr 67, poz. 759.

Rozporządzenie Ministra Edukacji Narodowej i Sportu z dnia 23 kwietnia 2004 r. w sprawie szczegółowych zasad sprawowania nadzoru pedagogicznego, wykazu stanowisk wymagających kwalifikacji pedagogicznych, kwalifikacji niezbędnych do sprawowania nadzoru pedagogicznego, a także kwalifikacji osób, którym można zlecać prowadzenie badań i opracowywanie ekspertyz, Dz.U. 2004 Nr 89, poz. 845.

Rozporządzenie Ministra Edukacji Narodowej i Sportu z dnia 4 lutego 2005 r. zmieniające rozporządzenie w sprawie szczegółowych zasad sprawowania nadzoru pedagogicznego, wykazu stanowisk wymagających kwalifikacji pedagogicznych, kwalifikacji niezbędnych do sprawowania nadzoru pedagogicznego, a także kwalifikacji osób, którym można zlecać prowadzenie badań i opracowywanie ekspertyz, Dz.U. 2005 Nr 41, poz. 386.

Rozporządzenie Ministra Edukacji Narodowej z dnia 15 grudnia 2006 r. w sprawie szczegółowych zasad sprawowania nadzoru pedagogicznego, wykazu stanowisk wymagających kwalifikacji pedagogicznych, kwalifikacji osób, którym można zlecać prowadzenie badań i opracowywanie ekspertyz, Dz.U. 2006 Nr 235, poz. 1703.

Rozporządzenie Ministra Edukacji Narodowej z dnia 7 października 2009 r. w sprawie nadzoru pedagogicznego, Dz.U. 2009 Nr 168, poz. 1324.

Ustawa z dnia 7 września 1991 r. o systemie oświaty, Dz.U. 1991 Nr 95, poz. 425.

Ustawa z dnia 4 marca 1994 r. o zmianie ustawy o systemie oświaty, Dz.U. 1994 Nr 53, poz. 215.

Ustawa z dnia 21 lipca 1995 r. o zmianie ustawy o systemie oświaty oraz niektórych innych ustaw, Dz.U. $1995 \mathrm{Nr}$ 101, poz. 504. 
Ustawa z dnia 25 lipca 1998 r. o zmianie ustawy o systemie oświaty, Dz.U. 1998 Nr 117, poz. 759 .

Ustawa z dnia 21 grudnia 2000 r. o zmianie ustawy o systemie oświaty, Dz.U. $2000 \mathrm{Nr}$ 122, poz. 1320 .

Ustawa z dnia 23 sierpnia 2001 r. o zmianie ustawy o systemie oświaty, ustawy - Przepisy wprowadzające reformę ustroju szkolnego, ustawy - Karta Nauczyciela oraz niektórych innych ustaw, Dz.U. $2001 \mathrm{Nr} 111$ poz. 1194.

Ustawa z dnia 15 marca 2002 r. o zmianie ustawy o systemie oświaty oraz niektórych innych ustaw, Dz.U. $2002 \mathrm{Nr} 41$ poz. 362.

Ustawa z dnia 27 lipca 2002 r. o zmianie ustawy o systemie oświaty, Dz.U. 2002 Nr 141, poz. 1185.

Ustawa z dnia 27 czerwca 2003 r. o zmianie ustawy o systemie oświaty oraz o zmianie niektórych innych ustaw, Dz.U. 2003 Nr 137, poz. 1304.

Ustawa z dnia 14 maja 2004 r. o zmianie ustawy o systemie oświaty, Dz.U. 2004 Nr 162, poz. 1690.

Ustawa z dnia 26 stycznia 2007 r. o zmianie ustawy o systemie informacji oświatowej oraz ustawy o systemie oświaty, Dz.U. $2007 \mathrm{Nr}$ 42, poz. 273.

Ustawa z dnia 25 lipca 2008 r. o zmianie ustawy o systemie oświaty, ustawy - Karta Nauczyciela oraz ustawy o postępowaniu w sprawach nieletnich, Dz.U. $2008 \mathrm{Nr}$ 145, poz. 917.

Ustawa z dnia 19 marca 2009 r. o zmianie ustawy o systemie oświaty oraz o zmianie niektórych innych ustaw, Dz.U. $2009 \mathrm{Nr} 56$, poz. 458.

\section{Reconstruction of a legal culture of school based on (changes in) legal regulations in the area of educational supervision}

\section{Summary}

The article is a part of a broader analysis related to the topic of the legal culture of the school. In this paper I focus on only one component of the legal culture of school-legal regulations, which I treat as a culture text. As an example, I have chosen the legal provisions relating to the educational supervision. The research problem pursued under this study is: What are the characteristics of the legal culture of school due to legal regulations related to the educational supervision? By analyzing such categories as: stability, degree of saturation legal regulations in this area, consistency between the objectives articulated of educational supervision and interpretation of specific legal regulations, I conclude serious symptoms of disfunctionality legal culture of school in this area.

Keywords: legal culture, school, educational supervision, educational law. 